\title{
THE ROLE OF INDONESIAN GOVERNMENT IN IMPROVING COFFEE COMPETITIVENESS IN THE EU-INDONESIA PARTNERSHIP AND COOPERATION AGREEMENT FRAMEWORK
}

\author{
Syahrul Salam, S.Pd., M.Si \\ Sindy Yulia Putri, S.Pd., M.Si \\ Faculty of Social and Political Sciences \\ Universitas Pembangunan Nasional Veteran Jakarta
}

\begin{abstract}
Indonesia is a crucial trading partner for the European Union (EU) and vice versa. Indonesia as one of ASEAN member countries contributes $36 \%$ of ASEAN's GDP with a population of 255 million (equivalent to almost half the ASEAN population). Indonesia and the EU further strengthen economic cooperation through the framework of the EU-Indonesia Partnership and Cooperation Agreement (PCA) cooperation. In the framework of the collaboration, most of Indonesia's exports to EU countries are in the form of agricultural and plantation commodities. For plantation commodities, coffee is Indonesia's leading export commodity with the potential to increase national economic growth. However, Indonesian coffee production has not been fully able to control EU market share. Although Indonesia is the third largest coffee producer in the world, Indonesia only controls $4.17 \%$ of the EU coffee market share. This is because only a small portion of Indonesian coffee is produced based on EU standards such as sustainability standards. Therefore, the Indonesian Government seeks to improve the competitiveness of Indonesian coffee commodities, such as production, quality of coffee, quality standards, human resources, and government coordination with coffee / private sector entrepreneurs.
\end{abstract}

Keyword: Indonesia, EU, Coffee, Competitiveness 


\section{Preface}

The era of globalization which is characterized by massive flows of increased movement of goods and services indirectly requires each state to be able to compete in the global market. The global situation has made the Free Trade Agreement (FTA) cooperation between Indonesia and the European Union (EU) states manifested in the form of EU-Indonesia Partnership and Cooperation Agreement (PCA) as a crucial matter. Indonesia is a potential trading partner for the EU and vice versa, moreover Indonesia's centrality is also highly calculated in ASEAN. In addition, Indonesia is also the sixth ASEAN state to initiate bilateral FTAs with EU, after Singapore (2010), Malaysia (2010), Vietnam (2012), Thailand (2013) and the Philippines (2015). In July 2016, EU has completed negotiations on bilateral agreements with Singapore (2014) and Vietnam (2015). In this case, EU-Indonesia PCA is a fundamental for carrying out some dialogues in the political-economic realm continuously and increasing the degree of bilateral diplomacy to higher level. The agreement also provides a legal framework to work together on a broader spectrum, such as human rights and democracy, environment, education, trade and investment (European Commission, 2016).

In the EU-Indonesia PCA agreement, there are four priority areas of cooperation, such as education, human rights and democracy, environment, trade and investment. Through the EU-Indonesia PCA mechanism, Indonesia can optimize exports of agricultural and plantation commodity, such as coffee (European Commission, 2016). Coffee is one of the plantation commodities that have an important role in supporting the increase of non-oil and gas exports in Indonesia. Indonesia is the third largest producer state and the fourth largest exporter of coffee on the world market (Kustiari, 2007). In 2013, Indonesia exported 19\% of total exports for agricultural commodities (UN Comtrade 2013). The amount of coffee exports in Indonesia has a promising potential for economic development. The types of coffee products are exported in the form of coffee beans, raw coffee, roasted coffee beans, and in the form of processed coffee (coffee powder). But most of Indonesia's coffee exports to foreign markets are dominated by coffee beans rather than processed coffee. For this type of coffee, robusta and Arabica coffee is still the main source of Indonesian coffee exports to the United States and EU (EU-Indonesia Business Network, 2016).

Although Indonesian coffee has good potential, Indonesian coffee production has not been able to control EU market share. In fact, Indonesia is only able to control $4.17 \%$ of the EU coffee market share. This is because only a small portion of Indonesian coffee production is in line with sustainability standards in EU's regulation. Even though, EU is the biggest global 
market that concern about sustainability. In addition, EU also requires traceability or tracking of coffee products ranging from the beginning of resources to available at the consumer table and consistency in quality assurance in providing quality products (Indonesian Trade Promotion Center Milan, 2016:5-6). Then, the value of Indonesian coffee exports tends to fluctuate in recent years. The event was caused by several things, namely (1) Influence of climate change. Domestic coffee production continues to decline, so of course Indonesia's coffee exports to EU also decreased; (2) The addition of the world's giant coffee processing industry that controls fast-food market share with products that are harmonized with the tongue of coffee enthusiasts, so that Indonesian coffee is increasingly difficult to compete; (3) Decrease in demand from importing states (in this context EU states) (Sari, 2016:5).

Referring to the previous explanation, that coffee is one of the plantation commodities that have great potential for European market penetration. But Indonesia's coffee exports are still not optimal, due to few non-tariff barriers. Indonesia is facing these obstacles, so that Indonesian coffee has difficulties to compete in the global market. In other hand, the proliferation of coffee exporters from several states is increasingly high, such as Brazil, Mexico and Vietnam. Therefore, this paper will be more elaborative in examining how the Indonesian Government's efforts to improve the competitiveness of coffee commodity exports to EU states in the framework of EU-Indonesia PCA cooperation.

\section{Discussion}

\section{Global Value Chain (GVC) in International Cooperation Framework}

This paper uses the concept of the Global Value Chain (GVC) concept to analyze the Indonesian government's efforts to increase the competitiveness of coffee exports to EU states. According to Kaplinsky and Morris, the GVC analysis framework is defined as the whole series of stages of a product or service through various phases of production, delivery to consumers, and recycling or post use. Furthermore, starting points in GVC are the added value gained through the upgrading process, namely the local industries capability to carry out innovation. It will impact to improve the competitiveness in global market and be able to respond the development of competitor's innovative (Kaplinsky \& Fitter, 2001).

The upgrading process itself consists of two types, namely static upgrading and dynamic upgrading. Static upgrading is an effort to provide unique things that difficult to imitate, and durable elements. Static upgrading includes providing things that can be added value to consumers, such as timely service, developing unique abilities, and creating things that are difficult to imitate. While dynamic upgrading is related to the right way or solution so that 
local companies have capacities to improve their competitiveness dynamically and continuously. Dynamic upgrading consists of four types, namely (1) Upgrading process: increasing the efficiency of internal processes within the company, so that the company can be better than its competitors; (2) Upgrading of products: introducing new products or developing and modifying old products faster than competitors; (3) Functional upgrading: increasing the goods value by changing activities in a company or by changing its position in the GVC chain; (4) Chain upgrading: moving to a new GVC chain (Kaplinsky, 2013:15-16).

In line with the above explanation, in understanding the state role in the upgrading process, this paper will focus on policy rents. Furthermore, policy rents will be able to describe the effectiveness of government support where efficient government policies will make it easier for companies to build economic rents through the provision of quality human resources, better infrastructure, and better financial support than other competing states. Even the government can create obstacles for foreign competitors to protect domestic industries. The capacity to apply policy rents depending on the capacity of relevant actors who are able to design and implement policies and are able to use the opportunities created by policy makers in other states (Kaplinsky, 2013:15-16).

Government policy rent that is able to protect domestic industries will be better understood if it refers to the concept of Governed Interdependence (GI) initiated by Linda Weiss. GI is a coordination system based on cooperation between government and industry where both of them play strong role. A policy is considered effective or not, depending on the relationship between government and industry. The relationship can be seen in all four GI types, namely First, Disciplined Support, in this type of government support in the form of regulation. Economic changes that occurred in the beginning were initiated by the public sector. If there are enterprises that reach the public goals, they will be given subsidies. The provided subsidy aims to make enterprise do something that is desired by the government, rather than seeking its own profit. Disciplined support is used as a way to measure the results of policy objectives and ensure that public conditions can be accounted for. Disciplined support also aims to achieve standard upgrading quality. Second, the Public risk absorption model, namely the government has a role to reduce the risks that arise. This second type was originally used by the government, so that the industry will fast grow up and it will stimulate the emergence of new industries. In addition, the government also mediates between producers and consumers in the market.

Third, Private sector governance, in this case the government appoints an agency or association to play a role in controlling prices, regulating production, increasing exports, and determining production standards. The government does not only play a direct role, but can 
also be behind the scenes to support national enterprises to partner with other foreign enterprises. Fourth, Public private alliances type, the government cooperates with the private sector to find innovation to create new products. Innovation is the main source of future growth. When referring to the concept of GVC and GI, government intervention is needed to improve the competitiveness of Indonesian coffee exports to EU states. The Indonesian government has realized significant efforts to improve Indonesian coffee competitiveness, such as coffee standardization policy, export regulation, and innovation in the form of coffee production technology.

\section{National Standardization of Indonesian Coffee (SNI)}

EU states implement a very high standardization system for coffee products. There are two parts of the regulation (buyer requirement) of imported products stipulated by the EU, namely (1) Legal requirements. These are rules established by EU and become the minimum requirements that must be fulfilled by producers to enter the EU market; (2) Non-legal requirements. These are provisions that set by private sector buyers or affiliated NGOs in almost all coffee producing states. The government's strategy as a policy rent in an effort to increase coffee exports on the EU market is by setting standardization of the quality of coffee production in accordance with the Indonesian National Standard. Indonesian National Standard (SNI) for coffee beans is a revision of SNI 01-2907-1999. This standard is formulated by the Agriculture 65-03 Technical Committee. This standard is also compiled and revised based on global market developments, such as International Coffee Organization (ICO) Resolution 407 and considering international requirements. In the ICO Resolution 407, there is a ban for trading the low quality coffee on 1 October 2002. This ban is one of the reasons of Indonesian government to improve the quality of Indonesian coffee through the implementation of quality standards and harmonization between Indonesian coffee quality standards and world coffee quality standards. Therefore, Indonesian government has carried out the improvements SNI 012907-1999 to be SNI 01-2907-2008 that explained the coffee quality requirements. There are two important things in coffee production, namely the specification of quality requirements and type of quality. In the specification of quality requirements, several elements will be tested, such as water content, dirt content, live insects, impurity level, and seed size. While on the type of quality, there are several quality grades, such as quality 1 , quality 2 , quality 3 , quality 4-A, quality $4-B$, quality 5 , and quality 6 . Through the specification of quality requirements and types of quality can be seen, how coffee competitiveness Indonesia against coffee from other states (National Standardization Institution, 2008). 
Within the framework of SNI, Indonesia uses ISO 1447. In the ISO, Indonesia applies the standard robusta coffee with $13 \%$ moisture content for processing dry processed and $12 \%$ for wet processed. While the ICO recommends the use of ISO 6673, where the recommended water content is $12.5 \%$ with a quality of 5 (the total value of defects or deffects $81-150$ ). In testing the percentage of water content, Indonesian coffee production did not encounter obstacles. But on the value of disability, Indonesian coffee encounters obstacles. In the low quality coffee criteria, it is determined that the maximum defect value for arabica is 86 , while for robusta is 150 . While the defect value of Indonesian arabica and robusta coffee is more than 150 and results in Indonesian Arabica and robusta coffee being in the quality 6 (total defect value or deffects 151-225). This shows, that the quality of Indonesian coffee is still low, because the value of the defect is still very high. Coffee that is in quality 6 has low competitiveness and will not be able to enter the export market (Badan Standardisasi Nasional, 2008).

In addition to the specification of quality and type of quality requirements, coffee competitiveness can also be explored through Revealed Comparative Advantage (RCA) analysis. Based on RCA analysis during the period 2001-2014, the RCA value of Indonesian coffee exports in ASEAN market was 10 while Vietnam had an RCA value of 53,4. The results of the RCA analysis indicate that Indonesia's coffee export competitiveness is still lower than Vietnam in ASEAN market. Then, referring to the data obtained from ICO (2016), domestic consumption of Indonesian coffee has an increasing trend, but with an uncertain annual percentage. From 2007 to 2011, the increase of Indonesia's domestic consumption of coffee tended to be stagnant but in 2012 and 2013, Indonesia's domestic coffee consumption increased by $10 \%$ and $13.6 \%$ and in period $2014-2015$ stagnated again with the percentage reaches $0 \%$ (Dradjat, 2007:171).

The low competitiveness of Indonesian coffee made it difficult for Indonesian coffee penetrating to the European market, especially EU states also formulated very strict policies for imported coffee products. Especially for the European community, the problem of prevention of food that endangers human health is a priority and cannot be negotiated. Coffee, as an ingredient in beverages, is suspected by Europeans to contain toxin that can harm human health, which can cause cancer. This toxin is Ochratoxin A (OTA) that produced by the fungus Aspergillus ochraceus. To prevent OTA, ICO has issued a document entitled Code of Practice with the document number ED 1763 Rev-1, dated 23 May 2003 which contains the handling of coffee during harvest, process, storage, and during the trip. If this limitation is really implemented, then the coffee detected containing OTA will be rejected by the importing countries and destroyed. The destruction of coffee will become a new problem for exporting 
and importing countries. For the EU community, coffee from Indonesia is indicated to be contaminated with OTA, thus weakening competitiveness (Zuhdi \& Suharno, 2015). The Indonesian government also plays a role in minimizing OTA toxins found in Indonesian coffee through better management. This will be elaborated in the next section regarding the development of Indonesian coffee technology.

\section{Indonesian Government Policy on Indonesian Coffee Exports}

The Indonesian Government's efforts to improve the competitiveness of national coffee commodities within the framework of EU-Indonesia PCA cooperation are the enactment of the Regulation of the Minister of Trade of the Republic of Indonesia, namely the Regulation of the Minister of Trade Number 26 / M-DAG / PER / 12/2005 replaced by Permendag Number 27 / M- DAG / PER / 7/2008, was changed again to the Regulation of the Minister of Trade Number 41 / M-DAG / PER / 9/2009 and was last changed in 2011 in the Minister of Trade Regulation Number 10 / M-DAG / PER / 5/2011. The emphasis in the regulation is on the ease of exporting coffee. One form of convenience regulated in the policy, such as exporters no longer attaches the receipt of payment of contributions to members of the Indonesian Coffee Exporters Association (AEKI) to obtain export permits. Changes are also found in the reporting mechanism for the realization of coffee exports to the government. In the old regulation, coffee exporters must send reports on the realization of coffee exports to the Ministry of Trade office. While in the new regulations, exporters simply report the realization of coffee exports online. Meanwhile, concerning the regulation of export of coffee is regulated in the customs tariff book of Indonesia HS No. 09.01 and 21.01, which contains the obligations of the exporter of coffee in accordance with the quality standards set by the Minister of Trade and accompanied by a certificate of origin. SKA is a certificate that is used as a accompanying document for coffee exported from all over Indonesia, which proves that the coffee is originated, produced, and / or processed in Indonesia. SKA in the form of an ICO is a non-preferential SKA, which functions as a supervisory document and / or accompanying documents from the origin of export goods to be able to enter a particular country. This quality standard policy is a government step in an effort to increase the competitiveness of coffee exports, especially in European Union countries (Simamora, 2014).

In addition to Regulation of the Minister of Trade, the Government of Indonesia also strives to improve and improve the productivity of crops and the quality of Indonesian coffee. The Ministry of Agriculture has and continues to conduct a series of research and collaboration with the Ministry of Trade and the technical team of the International Coffee Organization 
(ICO) in the Establishment of Indonesian National Standards (SNI) by the National Standardization Agency (BSN) for coffee and processed coffee products. Then, the Government of Indonesia also facilitated the implementation of the Warehouse Receipt at coffee production centers, such as in Bener Meriah District, Nangroe Aceh Darussalam Province. These policies proved to be able to encourage the growth of coffee exporters in various regions, so that in 2011 for example, the number of Coffee Registered Exporters (ETK) and Temporary Coffee Exporters (EKS) in Indonesia amounted to 377 companies (Sudjarmoko, 2013:106).

Several other Indonesian Government policies to increase export value and quality of coffee are by improving product quality, adjusting coffee types to market demand and promoting increased domestic consumption and exports. According to the Indonesian Trade Promotion Center, Indonesia can carry out a number of specific strategies to expand to the EU coffee market, such as (Kementerian Perdagangan, 2016).

1. Take part in the Specialty Coffee Association of Europe (SCAE) exhibition. SCAE is the largest coffee exhibition in Europe which is routinely held every year. This exhibition will create a network between Indonesian exporters and importers, retailers, agents, roasters, baristas and distributors throughout the EU.

2. Education and Knowledge Program on Indonesian Coffee. The goal is to make baristas, and coffee lovers become familiar with the peculiarities of Indonesian coffee (types of coffee from Java, Sumatra, Bali, Sulawesi, and so on). This program is intended to combine coffee cupping and screening films from Indonesian coffee. This program is held once a month.

3. Knowledge program for buyers. The aim is to maintain good government relations and attention to importers, baristas and roasters who each contribute to the formation of the image and value of Indonesian coffee exports. This program is also accompanied by the submission of placards and certificates to the CEO of Indonesian companies.

4. Collaborate with the Chamber of Commerce, Deutsch-Indonesische Industrie und Handelskammer (Indonesia-Germany Economic Association) and other associations. This strategy aims to build relationships with local business chains and lobby and utilize their experience and expertise to provide export / import training / workshops and entrepreneurial skills to the Indonesian diaspora.

In line with the above, when referring to the governed interdependence theory developed by Linda Weiss, the role of the government is represented through the enactment of Regulation of the Minister of Trade No. 10, 2011 which contains the standardization of quality 
and ease or leeway in exporting. The Regulation of the Minister of Trade is able to stimulate the presence of new coffee industries. Furthermore, the Government succeeded in mediating the relationship between producers and consumers especially in the framework of the EUIndonesia PCA cooperation.

\section{Indonesian Coffee Technology Development}

According to the Ministry of Agriculture's Post-Harvest and Business Development Directorate (2013), more than 65\% of Indonesia's coffee exports are grade IV and above and are classified as low quality coffee which is subject to export restrictions. The low quality of coffee production such as robusta coffee is mainly caused by garden management, harvesting, and inadequate post-harvest handling because almost all robusta coffee is produced by smallholder plantations. In a very difficult world coffee market situation, Indonesia needs to develop certain strategies that can boost the value of coffee exports on the EU market (Ministry of Trade, 2016).

The Indonesian government has implemented various strategies to develop domestic coffee production for three decades. In terms of area, it has shown a significant increase. In 1980, coffee plantation area amounted to 707,464 ha and increased to 1,268,478 ha in 2010 . The government has carried out various coffee intensification activities in seven provinces in 11 districts covering 13,510 ha, and expansion of 4,600 ha of arabica coffee and robusta coffee rejuvenation. ha in 12 provinces in 20 districts. This development needs to be supported by technology and post-harvest facilities that are suitable with the conditions of farmers so that they are able to produce coffee beans with quality in accordance with the Indonesian National Standard (SNI). The existence of a definite quality guarantee, availability in sufficient amount of time, and timely supply, as well as sustainability is a necessary condition for community coffee to be marketed at a more favorable price level. Along with the increasing demands of consumers for safe and environmentally friendly products, the reference standard of quality of coffee beans must accommodate the principles of good and true post-harvest handling (Good Handling Practices-GHP) and good farming practices (Good Agricultural Practices-GAP). GAP is a standard of work in every agricultural business so that the production produced meets international standards. The application of GHP and GAP is a guarantee for consumers, that the products marketed are derived from the results of a series of processes that are efficient, productive, and environmentally friendly (Mayrowani, 2013:1).

One of the main activities in improving the quality of Indonesian coffee is the use of advanced post-harvest technology. Post-harvest activities of agricultural products can be 
grouped into two stages, namely (1) primary post-harvest or handling and (2) post secondary harvesting or processing. Post-harvest technology both primary and secondary have an important role in increasing the added value of agricultural commodities through the processing of agricultural products. Post-harvest technology makes farming more efficient from the micro side and is an opportunity to increase production by reducing the level of yield loss at harvest and low quality results (Mayrowani, 2013:32).

Good post-harvest technology will be useful to minimize the potential for the growth of OTA fungi or toxins. To overcome the OTA issue, the AEKI Lampung BPD has collaborated with the Indonesian Coffee and Cocoa Research Center to conduct training and counseling to anticipate the possibility of OTA contamination in coffee originating from Lampung. The recommended practical way is to avoid storing coffee with a water content of $>14 \%$ starting from the initial processing (post-harvest) so that it can avoid the onset of fungi in coffee early. FAO research results in collaboration with the Indonesian Center for Coffee and Cocoa show that Indonesian coffee beans are still safe from OTA. The results of this study have somewhat reduced the development of the issue of the existence of OTA in coffee beans from Indonesia (Dradjat, 2007:171).

\section{Conclusion}

The Indonesian government has realized various policies to improve the competitiveness of national coffee commodities in the EU-Indonesia PCA agreement, such as the first, private sector governance, in this category the Indonesian government's efforts are marked by the establishment of the Indonesian National Standard (SNI). Determination of this standardization is a government effort to spur local coffee exporting industries to improve the quality of coffee bean products. In the determination of SNI, the Government of Indonesia collaborates with the International Coffee Organization (ICO) so that the quality of Indonesian coffee is recognized in the international market. Second, public private alliances type, in this category the government innovates coffee bean products using post-harvest technology. Third, the government appoints the Ministry of Trade to standardize the quality and governance of special coffee export requirements to EU member countries. In this case, the government also has an important role as a mediator between producers and consumers, both domestically and abroad.

\section{Suggestion}


The global situation has made the Free Trade Agreement (FTA) collaboration between Indonesia and EU countries in the form of EU-Indonesia Partnership and Cooperation Agreement (PCA) a necessity for both parties. For Indonesia, the EU-Indonesia PCA cooperation framework is a great opportunity to increase coffee commodity exports in the EU market, considering that Indonesia is the third largest coffee producing country in the world. The Indonesian government is aware of the advantages of national coffee commodities, so the government is trying to improve the competitiveness of coffee commodities in the international sphere. But the effort is still not optimal. This was marked by the lack of the role of government in the disciplined support category, namely in the form of subsidies to coffee exporting companies when they have achieved public goals or in other words able to compete in national and international order. Therefore, the government should be wiser in supporting coffee entrepreneurs to improve the quality of coffee in accordance with national quality standards and at the same time penetrate the EU market share better.

\section{Bibliography}

"Association of Southeast Asian Nations". European Commission, accessed by $\underline{\mathrm{http}: / / \text { ec.europa.eu/trade/policy/countries-and-regions/regions/asean/ }} \quad$ (04/12/2016, $10: 16$ WIB).

Dradjat, Bambang, dkk. "Ekspor dan Daya Saing Kopi Biji Indonesia di Pasar Internasional: Implikasi Strategis Bagi Pengembangan Kopi Biji Organik”. Pelita Perkebunan 2007.

"Indonesia". European Commission, accessed by http://ec.europa.eu/trade/policy/countriesand-regions/countries/indonesia/ (04/12/2016, 10:16 WIB).

"Indonesia". EU-Indonesia Business Network, accessed by http://www.eibn.org/en/page/indonesia_content/45\#L1 (04/12/2016, 21:22 WIB).

Kaplinsky, Raphael. "GLOBAL VALUE CHAINS, WHERE THEY CAME FROM, WHERE THEY ARE GOING AND WHY THIS IS IMPORTANT". IKD Working Paper No. 68, November 2013. Development Policy and Practice, The Open University, accessed by http://citeseerx.ist.psu.edu/viewdoc/download?doi=10.1.1.724.6304\&rep=rep1\&type=pdf (11/09/2018, 08:07 WIB).

Kaplinsky, Raphael \& Fitter, R. "Who Gains from Product Rents as The Coffee Market Becomes More Differentiated? A Value Chain Analysis", IDS Bulletin Paper, Institute of Development Studies: Sussex, 2001.

"Kopi Indonesia di Pasar Jerman: Fakta dan Strategi". Badan Pengkajian dan Pengembangan Kebijakan Perdagangan. Kementerian Perdagangan, accessed by http://bppp.kemendag.go.id/media content/2017/08/Kopi Indonesia di Pasar Jerman-

Fakta_dan_Strategi.pdf $(10 / 09 / 2018,18: 47$ WIB). 
Kustiari, Reni. "Perkembangan Pasar Kopi Dunia dan Implikasinya Bagi Indonesia". Pusat Analisis Sosial Ekonomi dan Kebijakan Pertanian. Forum Penelitian Agro Ekonomi. Vol 25 No.1, Juli 2007, accessed by http://pse.litbang.pertanian.go.id/ind/pdffiles/FAE25-1d.pdf (04/12/2016, 21:12 WIB).

Laraswati, Siti Kurnia \& Salamah, Muna Zatul. "Peluang, Hambatan, dan Kebijakan Ekspor Kopi Indonesia ke Pasar Amerika Serikat". Unmul. Vol. 3 No 1, 2015, accessed by http://ejournal.hi.fisip-unmul.ac.id/site/wp-content/uploads/2015/11/857.-Siti-Kurnia-L10020450269.pdf $(04 / 12 / 2016,21: 22$ WIB).

"Market Brief: Peluang Usaha Produk Biji Kopi (HS090111) di Italia". Indonesian Trade Promotion Center ITPC Milan. 2016, accessed by http://itpcmilan.it/wpcontent/uploads/2016/06/Market-Brief-2016-ITPC-Milan-Peluang-Usaha-Produk-Biji-KopiFinal.pdf $(04 / 12 / 2016,22: 50 \mathrm{WIB})$.

"Market Brief Kopi di Pasar Jerman". Kementerian Perdagangan Republik Indonesia. ITPC Hamburg. January 2013, accessed by http://djpen.kemendag.go.id/app frontend/admin/docs/researchcorner/1561376297761.pdf (04/12/2016, 22:41 WIB).

Mayrowani, Henny. "Kebijakan Penyediaan Teknologi Pascapanen Kopi dan Masalah Pengembangannya". Pusat Sosial Ekonomi dan Kebijakan Pertanian. Forum Penelitian Agro Ekonomi. Vol. 31 No. 1, Juli 2013, accessed by http://pse.litbang.pertanian.go.id/ind/pdffiles/FAE31-1c.pdf (13/12/2016, 21:40 WIB).

Simamora, Sehat Dinati, et al. "Market Brief Langkah dan Strategi Ekspor ke Uni Eropa: Produk Kopi”. APINDO-EU ACTIVE, Juli 2014.

Sudjarmoko, Bedy. "Prospek Pengembangan Industrialisasi Kopi Indonesia", SIRINOV, Vol 1, No 3, Desember 2013, Balai Penelitian Tanaman Rempah dan Aneka Tanaman Industri.

Standar Nasional Indonesia (SNI) 01-2907-2008. ICS 67.140.20. Badan Standardisasi Nasional, accessed by http://disbun.sulselprov.go.id/files download/SNI 29072008 Biji Kopi.pdf (10/12/2016, 22:13 WIB).

"UN Comtrade 2013" di dalam Desi Ratna Sari, dkk. "Analisis Posisi Ekspor Kopi Indonesia di Pasar Dunia". Universitas Riau. Vol. 3 No. 1, February 2016, accessed by http://download.portalgaruda.org/article.php? article $=385377 \& \mathrm{val}=6448 \&$ title $=$ ANALISIS $\% 2$ 0POSISI\%20EKSPOR\%20KOPI\%20INDONESIA\%20DI\%20PASAR\%20DUNIA $(04 / 12 / 2016,22: 50 \mathrm{WIB})$.

Weiss, Linda. "Governed interdependence: Rethinking the government- businessrelationship in East Asia, The Pacific Review, 8:4, 589-616 accessed by http://dx.doi.org/10.1080/09512749508719160 (11/09/2018, 08:12 WIB).

Zuhdi, Fadhlan \& Suharno. "Analisis Daya Saing Ekspor Kopi Indonesia dan Vietnam di Pasar ASEAN 5". Habitat. Vol. 26 No. 3. Desember 2015. Departemen Agribisnis, Fakultas Ekonomi dan Manajemen. Institut Pertanian Bogor. 